\title{
Dispute of the Contracts: A Case from Sikta Irrigation Project, Banke, Nepal
}

\author{
Anjay Kumar Mishra*, Prakash Yadav** \& P. S. Aithal*** \\ *Post-Doctoral Research Scholar, Srinivas University, India, and Associate Professor, Madan \\ Bhandari Memorial Academy Nepal, Urlabari3, Morang, Nepal \\ OrcidID: 0000-0003-2803-4918; Email: anjaymishra2000@ gmail.com \\ **Engineer, Khando River Management Project, Saptari, Nepal \\ E-mail: prydv22@gmail.com \\ *** Professor, College of Management \& Commerce, Srinivas University, Mangalore, India \\ OrcidID: 0000-0002-4691-8736; E-mail: psaithal@gmail.com
}

Area of the Paper: Project Management.

Type of the Paper: Analytical Policy Research.

Type of Review: Peer Reviewed as per $|\mathrm{C}| \mathrm{O}|\mathrm{P}| \mathrm{E} \mid$ guidance.

Indexed In: OpenAIRE.

DOI: http://doi.org/10.5281/zenodo.5037030

Google Scholar Citation: IJCSBE

\section{How to Cite this Paper:}

Mishra, Anjay Kumar, Prakash Yadav, \& Aithal, P. S., (2021). Dispute of the Contracts: A Case from Sikta Irrigation Project, Banke, Nepal. International Journal of Case Studies in Business, IT, and Education (IJCSBE), 5(1), 169-185. DOI: http://doi.org/10.5281/zenodo.5037030.

International Journal of Case Studies in Business, IT and Education (IJCSBE)

A Refereed International Journal of Srinivas University, India.

Crossref DOI : https://doi.org/10.47992/IJCSBE.2581.6942.0108

(C) With Authors.

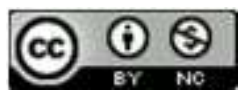

This work is licensed under a Creative Commons Attribution Non-Commercial 4.0 International License subject to proper citation to the publication source of the work.

Disclaimer: The scholarly papers as reviewed and published by the Srinivas Publications (S.P.), India are the views and opinions of their respective authors and are not the views or opinions of the S.P. The S.P. disclaims of any harm or loss caused due to the published content to any party. 


\title{
Dispute of the Contracts: A Case from Sikta Irrigation Project, Banke, Nepal
}

\author{
Anjay Kumar Mishra*, Prakash Yadav** \& P. S. Aithal*** \\ *Post-Doctoral Research Scholar, Srinivas University, India, and Associate Professor, Madan \\ Bhandari Memorial Academy Nepal, Urlabari3, Morang, Nepal \\ OrcidID: 0000-0003-2803-4918; Email: anjaymishra2000@ gmail.com \\ **Engineer, Khando River Management Project, Saptari, Nepal; E-mail: \\ prydv22@gmail.com \\ *** Professor, College of Management \& Commerce, Srinivas University, Mangalore, India \\ OrcidID: 0000-0002-4691-8736; E-mail: psaithal@gmail.com
}

\begin{abstract}
Purpose: Government of Nepal (GoN) is implementing many small, medium and large type of Irrigation Projects. Sikta Irrigation Project (SIP) is the National Pride Project implemented by the GoN. The command area of the project has 42766.00 ha and the beneficiary of the project have 46715 households consisting of 4,49,588 population of Banke district. The overall objective of the study is to assess the consequences of delay and dispute of the selected contracts of Sikta Irrigation Project, Banke, Nepal.

Design/Methodology/Approach: Using secondary data of the contract the mean planned duration is compared with mean actual duration to analyze delay analysis and Disputes of the contract have been interpreted based on standards of contract using content analysis.

Findings/Result: The mean planned duration of the contracts under the study is 17.42 months and mean actual time 32.28 months with a standard deviation of 7.72 months and meantime variance is 13.46 months behind the schedule and meantime overrun is 14.85 months. Dispute resolution of only Papu costal JV has been analyzed. The contracts need to be rectified in terms of time by proper scheduling and resource leveling based local calendar. Hope the new amendments (PPMO 10th) of time extension will be helpful for the timely completion of contracts.
\end{abstract}

Originality/Value: Action research to enhance the performance of Projects by avoiding Disputes.

Paper Type: Analytical Policy Research.

Keywords: Meantime, Standard deviation, time overrun, Joint Venture, Dispute Analysis

\section{INTRODUCTION :}

Nepalese economy is moving around the vicious circle of poverty. To break this type of circle the country needs to raise the income level of people engaged in Agriculture as more than $65 \%$ people depends on agriculture (Mishra and Aithal, 2021) [1]. Irrigation being backbone of agriculture, The Sikta Irrigation Project is situated at provenance no. 5 in the Banke District of the Mid-Western Development Region is a hope. Originally, the Project envisaged constructing irrigation infrastructures to provide irrigation water to a cultivable command area 33,766 ha including the rehabilitation of Dunduwa Irrigation system, constructed by Indian Cooperation Mission in 1964, on the right side of the Rapti River. Similarly, the project will cover additional 9000 ha of land lying on left bank of Rapti River including 1,800 ha command area of the existing Rajkulo Irrigation System and 2,500 ha land of Fattepur Irrigation System. Thus, the SIP would irrigate 42,766 ha almost all the low lands of the Banke District and its economic impact could be significant for this development region (SIP Master plan, 2019) [2].

The Project area is situated in a sub-tropical monsoon type climatic zone. The median annual rainfall is $1328 \mathrm{~mm}$ of which more than $80 \%$ occurs during the month of June to September. The temperature in the project area ranges from minimum of 50C in the month of January to the maximum of $440 \mathrm{C}$ in the 
month of June. The range of humidity falls between $60 \%$ in May to $85 \%$ in January.

The sedimentary soils in the command area of the Project are well suited to irrigation of a wide range of crops, such as rice, wheat, maize, cotton, fruits, vegetables, pulses and tobacco. The project, which would supply irrigation water from the Rapti River by run-of-the-river gravity flow is the only viable alternative to provide large scale irrigation in this area. Ground water potential is limited to some pockets in the southern part of the district.

The water source for the Project is the Rapti River, located in the mid-western region of Nepal, between elevations of 170 to $4,000 \mathrm{~m}$ above sea level. The total length of the river to the diversion site is around $280 \mathrm{~km}$, and the catchment area covers $5450 \mathrm{~km} 2$. The flood analysis for a 100 -year return period results in a maximum discharge of 8,255 Cumecs. The decrease in the river discharge during the dry season will impose some restrictions on cropping intensities under irrigation. During the most critical period of very low discharge from mid-April to mid-July limited diversion would be permissible because of the need to protect and maintain the aquatic ecosystem, downstream of the diversion head works.

Some $60 \%$ of the people own either no land or small farms less than 0.5 ha. The average landholding in the Project area is 0.84 ha. A minority of people in the Project area holds a relatively large proportion of the land, which is usually not tilled by themselves but rented out to sharecropping tenants.

The success of any construction project is measured in terms of its performance on schedule, cost, quality and no-dispute. There are many factors that obstruct performance of construction causing time overrun or cost overrun or both. The project performance is measured base on timely completion, within the budget, required quality standards and customer's satisfaction (Chiluwal \& Mishra, 2017) [3]. As a consequence of poor performance, the projects mainly face the problem of time overrun and cost overrun. Maskey \& Mishra (2018) [4] mentioned that for productivity, dependency on existing facilities, lack of rentable facilities and for the contractor, construction delay refers to the higher costs, longer work duration, increased Laboure, higher material and equipment costs.

The significance of this study is to identify time overrun and cost overrun of the Sikta Irrigation Project. The time overrun and cost overrun is the serious issues faced by construction projects due to poor performance. The overall goal of the Sikta irrigation project is to contribute to the National Development objectives of the government. The provision of irrigation facilities together with the improvement of agricultural, support services which would improve the productive capacity of farmers so that agricultural production income would be increased are the living standard of the people in Banke district will be increased. This study of helps to improve the performance of contractors.

\section{OBJECTIVES :}

The general objective of the study is to assess consequences of delay and dispute of the selected contracts.

\section{LITERATURE REVIEW :}

\subsection{Time Overrun of Construction Project:}

According to Hassan, et al (2016) [5], delay in construction projects means a prolonged duration of the project implementation from the time has been planned and listed in the contract document. Delay on work completion is a deficiency of the productivity level of and of course all it will result in in efficiency in financing, both in the form of direct financing spent on government projects and in the form of inventory swings and losses on private projects (Hassan, et al, 2016) [5].

Research done earlier indicates that "changed work complicates a project and invites delays" (Mishra and Aithal) [6]. Delays that are non-excusable (contractor caused) "expose a contractor to delay claims of its subcontractors and liquidated damages" (Mishra and Bhandari, 2020) [7]. Delays that are compensable (owner caused) need the support of specially contractors who need to be nominated at the appropriate time (Gil, 2001) [8].

Ghimire and Mishra (2019) [9] stated that the construction delays are often resulting of miscommunication between contractors, subcontractors, owners and suppliers.

Moreover, the project delay is still happening and will continue to happen in the construction for various known and unknown reasons such as unexpected factors, bankruptcy from client, change in design during the construction, political issue, sudden price fluctuation, with projects manager in result of forcing him/her to leave before completing the assigned job. However, time and cost overrun may not be prevented entering but the evolving new technology like BIM, new methods and past experience 
could be used to reduce the impact from recognized risk factors, particularly in the undeveloped and developing countries (Yadav and Mishra) [10].

Time Overrun is one of the most significant issues being faced by the construction industry today. There are various factors responsible for the time overrun which requires serious attention to understand and address in order to achieve successful completion of projects on time. This is because time overrun has great impact to construction cost which can never be recovered (Mishra et al, 2020) [11].

\subsection{Provision for Time Extension Public Procurements of Nepal:}

The Sub-clause 35.1 of the General condition of Contract of the Bidding Document for the Procurement of the Works prepared by Public Procurement Monitoring office of Nepal (2017) [12] has stated that the time can be extended if a Compensation event occurs or a Variation is issued which makes it impossible for completion to be achieved by the Intended Completion Date without the Contractor taking steps to accelerate the remaining work, which would cause the Contractor to incur additional cost.

In Sub-clause 35.2 further mentioned that the employer has to decide whether and by how much to extend the Intended Completion Date within 21 days of the Contractor asking the Project Manager for a decision upon the effect of a Compensation Event of Variation and submitting full supporting information at least 7 days prior to the intended completion date. If the contractor has failed to give early warning of a delay or has failed to cooperate in dealing with a delay, the delay by this failure shall not be considered in assessing the new Intended Completion Date.

The granting of an extension of time for completion shall not entitle the contractor to any additional payment where in the opinion of the contractor, additional costs have been incurred as a result of the cause or the event for which an extension of time for completion has been granted, such costs shall be well documented and may be claimed separately in accordance with the provisions of the clause 20.1.0 (ICB SBD, 2017 as cited in Mishra et al.) [13].

The Section 56 of the Public Procurement Act of Public Procurement Monitoring Office, (2020) [12] has provisioned for the extension of period of procurement contract. Sub section (1) it states that provision relating to the extension of the term of a procurement contract shall be as provided for in the concerned procurement contract.

Sub section (2) states that notwithstanding anything contained in subsection (1), if the term of a procurement contract is to be inevitably extended due to force majeure, failure of the public entity to make available the things required to be made available by it or other reasonable grounds, the competent authority may, on an application by the person whom the contract has been awarded to, extend the term on the prescribed grounds.

Further, the section 120 of Public Procurement Monitoring Office (2020) [12] has made elaboration in line with the sub clause 56 of the Public Procurement Act of PPMO. Sub section (1), It states that if the work under the procurement contract cannot be completed within the time of such a contract due to the occurrence of conditions set out in Section 56 of the Act, the concerned construction entrepreneur, supplier, service provider of consultant, as the case may be, shall have to make an application, stating reasons therefor, to the concerned public entity for the extension of time period at least 21 days before the expiration of the term of such contract. Sub rule (1a) states that notwithstanding anything contained in sub-rule (1), in the case of a procurement contract which has been concluded and of which term has expired prior to the commencement of this sub-rule, the concerned construction entrepreneur, supplier, service provider or consultant shall make an application for the extension of term, not later than twentyone days of the commencement of this sub-rule.

Sub rule (2) upon receipt of an application pursuant to sub-rules (1) and (1a), the concerned competent authority may make, or cause to be made, necessary inquiry into the matter. In so making or causing to be made inquiry, the authority shall have regard to the following matters:

(a) Whether the concerned construction entrepreneur, supplier, service provider or consultant has made best efforts to complete the work under the procurement contract in time or not,

(b) Whether the concerned public entity has provided the construction entrepreneur, supplier, service provider or consultant with the matters required to be provided under the contract or not,

(b) whether the delay in work has been made because of the requirement of documents pursuant to Section 67A, of the Act or not,

(c) Whether the delay in work has been made because of a force majeure event or not, 
Sub-rule (3) if, upon inquiry made pursuant to sub-rule (2), the reason referred to in the application appears to be reasonable, the authority accepting the bid may extend the term if it is required to extend the term not exceeding fifteen percent of the original period of the contract, and the head of department may extend the term if it is required to extend the term exceeding the said period but not exceeding twenty five percent period of the term.

Sub rule (4) If there is a reasonable for extending the term of a period exceeding the period set forth in sub rule (3), the secretary of the concerned Ministry or entity may extend the term.

Sub rule (5) the decision on extension of the term referred to in sub-rules (3) and (4) shall be made within the period of the contract.

Sub rule (6) notwithstanding anything contained in this rule, no extension of term shall be so made as to exceed fifty percent of the original term of the contract.

Provided that if, in the case of any procurement contract concluded prior to 6 June 2019 (23 Jeasth 2076) [14] and for the extension of the period of which an application has been made, it appears on the basis of, inter alia, the technical report and upon an analysis of the work progress and remaining work that the work under the contract can be completed if the period is extended, the special class or equivalent officer of the concerned Ministry or entity may so extend the period not exceeding one year that such extension does not results in any additional financial burden on the public entity or project. In any addition financial burden on the public entity or project. In the case of one who fails to complete the work under the contract even within the period so extended, the performance security and other security or guarantee, if any, furnished by such a person shall be forfeited and the loss and damage resulted from such failure to complete the work shall be recovered in accordance with the prevailing law and such person shall be blacklisted and subject to action under the prevailing law.

Sub rule (7) If the term is not extended pursuant to sub-rules (3), (4) and (6) the contract shall be terminated.

Section 121 of the Public Procurement Monitoring Office (2020) is related to the Liquidity damages which states that if the work under the procurement contract could not be completed within the time specified in the contract due to the delay of the supplier, consultant, service provider or construction entrepreneur, as the case may be, he/ she shall have to pay to the Public Entity liquidated damages, generally of zero decimal zero five (0.05) percent of the contract of the contract price per day not exceeding ten percent of the contract price.

\subsection{Disputes/Claims in Construction Contract in Nepal:}

A dispute/claim as stated is demand for money, time or an adjustment as per the contract terms. The National Highway Institute, US Department of Transportation assumes that contractor believes a change exists but the owner disagrees and both Parties agree that a change exists but cannot agree on the impact and costs of the change. Problem associated with claims and disputes are unique in the Nepalese construction industry. One common thing in our context is that many of claims, which are initially launched and eventually abandoned. The main reason for this may be due to employ favored contract document in which the contractor's right is minimally protected. In addition, the other reason is the low level of knowledge regarding contractual rights and obligation among the contracting parties. Neither the employer nor the contractor gives adequate attention to the need for exhaustive provision in the contract. Therefore, it provides adequate grounds to give raise to a problem during contract execution (Mishra et al, 2018) [12]. There are many causes for emergence of disputes. A dispute arises when a demand is made by a party (either contractor or employer) and denied by the other and the contradiction is not accepted by the demanding party (either employer or contractor). The dispute originates due to disagreement on a decision or action taken by one party on the ground of effect to be borne by the other as consequence of the decision. It is found that many construction projects in all sector of development either completed or ongoing have suffered from time and cost overrun. A major reason for this is poor management of contract resulting in disputes leading to intermittent stoppage of works or slow progress or even abandonment of work requiring fresh call of tenders to engage a new contractor for execution. There is no such contract document, which is universally acceptable. Contract document differ from place to place due to difference in social and business norms and values, intellectual capacity, experiences in contracting of the parties and business environment. Therefore, contract document should be prepared talking into consideration of those matter mentioned above in order to minimize and to resolve the potential disputes. 
In construction contract, dispute may arise because of several factors. They could be broadly classified into three categories; Frivolous (playful) claims with practically no basis either in the contract or in law. Genuine claims, which are not entertained, by the client or his representative, because of their unwillingness to give decision for the fear of being questioned by audit, etc. Honest difference of opinion on the interpretation of contract of conditions (Mishra et al. 2018) [14].

Disputes are to be prevented and if it exists, its early resolution is important. To resolve disputes, several methods are in practices in the world. These methods are classified in two types. One is litigation and other ADR method. This study attempts to send some light in the condition of contract related to disputes in construction contract (Mishra et al. 2018) [14].

\section{RESEARCH METHODOLOGY :}

\subsection{Selection of Study Area:}

Sikta Irrigation Project is the National Pride Project, it is located at Provinance no 5 in Banke District. The water source for this project is West Rapti River, which originates from the mid-mountains in the Mid-Western Region of the country. The source of this irrigation system is perennial. There are two system of canal i.e., Eastern canal and Western canal. Eastern canal passes through Rapti Sonari Gaupalika and Narainapur Gaupalika its length $53.50 \mathrm{~km}$ and command area 9000 ha. There are 11 no's of secondary canal. Among them Rajkulo contains S1, S2, S3, S4 and Phattepur contains S5, S6, S7, S8, S8, S9, S10, S11. The length of secondary and tertiary canal is $145 \mathrm{~km}$. The discharge of Eastern canal 14 cumec. Western canal passes through Rapti Sonari Gaupalika, Dudwa Gaupalika, Kohalpur Nagarpalika and Baijnath Gaupalika. Its length is $45.25 \mathrm{~km}$ with trapezoidal canal section having the tail escape at the end and command area $33766 \mathrm{~km}$. The discharge of western canal 50 cumec. There are 7 no's of secondary canal. S1 (Sidhaniya branch, Length-19.6 km, Command Area-2100 ha), Dunduwa, (Length-23.50 km, Command Area-16000 ha), S2 (Gohawa, Length-3.4 km, Command Area-330 ha), S3 (Akalgherw, Length-5.7km, Command Area-1500ha), S4 (Persenpu, Length$11.80 \mathrm{~km}$, Command Area-1400 ha), S5 (Pidari, Length-7.3km, Command Area-1460ha), S6 (GaruwaGau, Length-18.80km, Command Area-9400 ha) are the secondary canal. The length of secondary and tertiary canal $233 \mathrm{~km}$. The ideal length of canal is $30 \mathrm{~km}$. The bed slope of canal is 1/7000. Present cropping intensity $168 \%$ and future cropping intensity $242 \%$. when project have been completed then beneficiary of the project has 46715 house hold and 449588 population of Banke district.

Sikta, which started construction 14 years ago in Magh 2063 (local year). It was supposed to be built at an average cost of Rs 12 billion. Five years after scheduled time, the project has started partially providing water to the farmers. The estimated cost of the project in the initial year 2061/062 was 12.80 billion. Later second revision and add scope of work the approved total financial cost of whole Project was NRS. 25.02 billion in fiscal year 2071/72. However, the cost of the Project has been increased to NRs 39.98 billion due to rectification of right main canal, some additional command area development and command area protection works, increased cost of Left main canal as per contract agreement, increased cost of Dunduwa irrigation system as per DPR, social cost to address social requirements of project affected area, increased cost of land acquisition, and inflation.

\subsection{Design and Data Collection:}

The research is ex-post facto research-based field performance as documentary study. The study depends on secondary data of contract documents and project documents. The researcher was at site for 2 years to document the study. Key Informant Interview using snowball technique has been applied to clear the ambiguities of documents and hidden information using formal and informal techniques.

\subsection{Data Analysis:}

As Built Method of delay analysis was done to assess entitlement, causation and damages during delay using content analysis. Degree of Dispersion using result from double hydrometer test as per given table 1.

\subsection{Design and Data Collection:}

The research is ex-post facto research-based field performance as documentary study. The study depends on secondary data of contract documents and project documents. The researcher was at site for 2 years to document the study. Key Informant Interview using snowball technique has been applied to 
clear the ambiguities of documents and hidden information using formal and informal techniques.

\subsection{Data Analysis:}

As Built Method of delay analysis was done to assess entitlement, causation and damages during delay using content analysis. Degree of Dispersion using result from double hydrometer test as per given table 1.

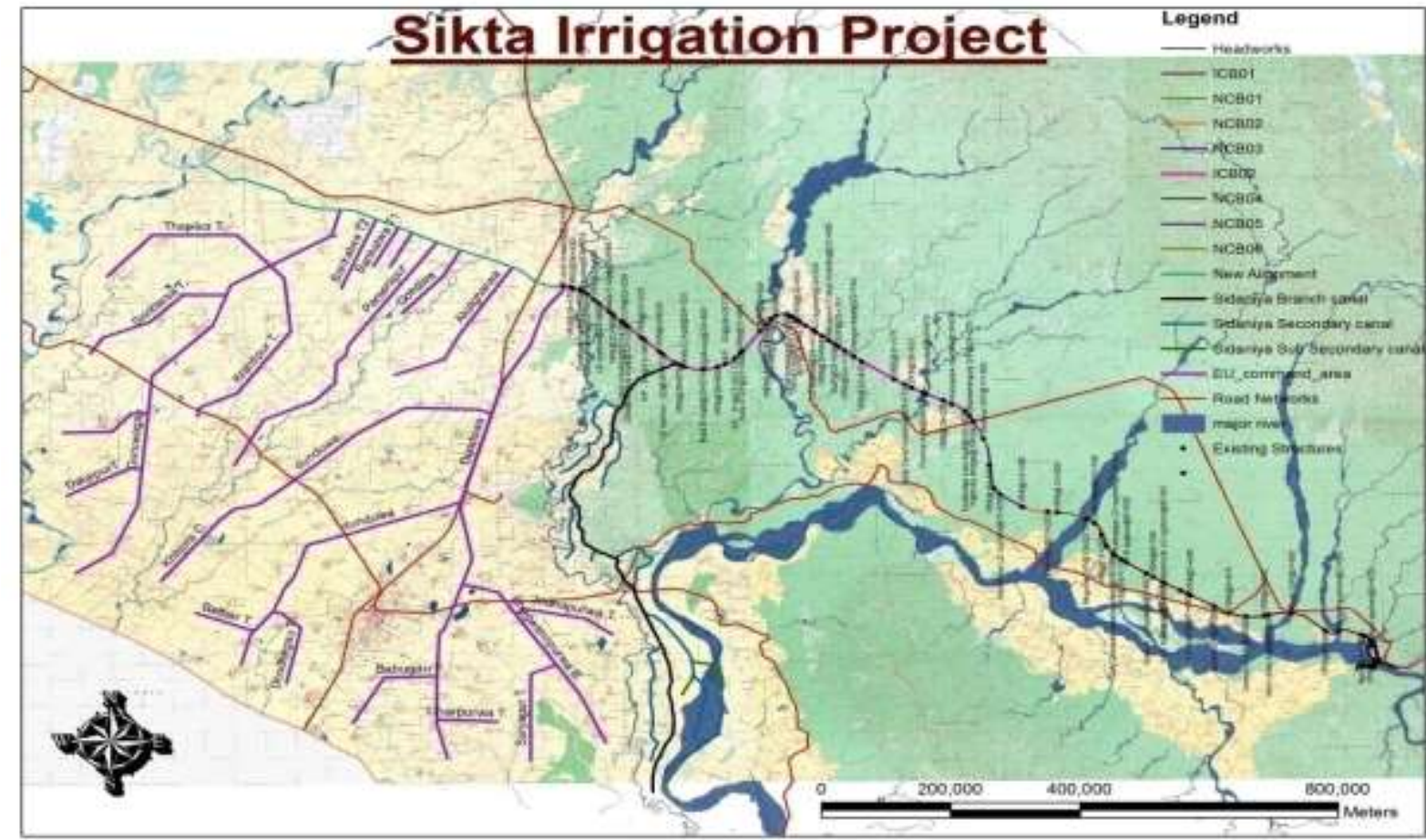

(Source: SIP DPR, 2014)

Fig.1: Sikta Irrigation Project Layout Map.

Table 1 : Degree of Dispersion using result from double hydrometer test

\begin{tabular}{|c|c|c|}
\hline S.N. & Dispersion & Degree of dispersion \\
\hline 1 & $<30$ & Non dispersive \\
\hline 2 & 30 to 50 & Intermediate \\
\hline 3 & $>50$ & Dispersive \\
\hline
\end{tabular}

\subsection{Validity and Reliability:}

The presence of researcher at working site for 2 years and documents verification gives validity of research and comparison with literature provides reliability.

\section{RESULTS AND DISCUSSION :}

\subsection{Time overruns of project:}

The time overrun of the completed project under the Sikta Irrigation Project has estimated time of 16 projects may differ project to project i.e., minimum 4 month and maximum 43 month. The overall project analysis delay completed project table 2 shows that average estimated time of projects is 22.06 months and average actual time 34.37 months. The average time overrun of the projects is 12.31 months with the ratio of 1.8. The four projects are cost overrun.

The running projects 14 in table 3 shows that average estimated time of projects is 17.42 months and average actual time 32.28 months. The average time overrun of the projects is 14.85 months with the ratio 1.96 and average time variance of the projects is 13.46 month behind the schedule. The project contract no. SIP/EMC/ICB-01 delay different causes due to decision of approval of site clearance of tree in canal alignment area and do not study IEE of quarry site so scarcity of construction material, disputes of fixing of canal alignment, pre monsoon/ unpredictable rainfall, bandh hartal covid-19 
lockdown. The different branches of western canal of the contract no SIP/RMC/AKL/NCB-01, SIP/RMC/GHW/NCB-01 SIP/RMC/PDR/NCB-01 and SIP/RMC/PSR/NCB-01 delay due to different causes such as delay decision to Land acquisition of canal alignment, delay decision of Kalo purja land, delay decision of tree clearance of canal alignment and pre monsoon, unavailability of construction material, Covid-19, lockdown.

Table 2: Beyond scheduled dated completed projects detail.

\begin{tabular}{|c|c|c|c|c|c|c|c|c|c|c|c|}
\hline$\dot{\dot{m}}$ & 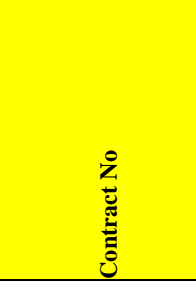 & 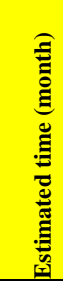 & 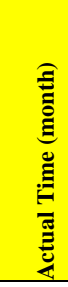 & 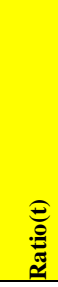 & 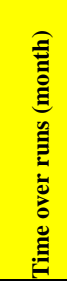 & 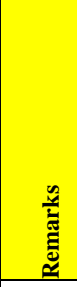 & 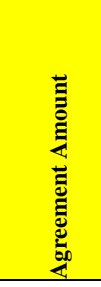 & 竎 &  & 里 & 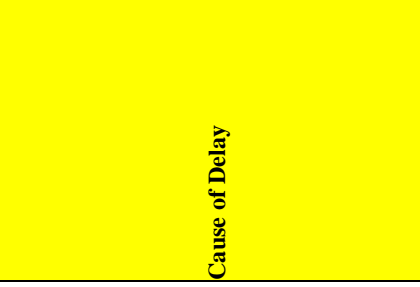 \\
\hline 1 & SIP/HW/ICB-02 & 43 & 54 & 1.3 & 11 & $t>1$ & 1109.27 & 1106.64 & -0.23 & $\mathrm{C}<1$ & $\begin{array}{l}\text { Delay due to excess rain, flood in river, } \\
\text { scope of work change, Scarcity of } \\
\text { material, political instability, Nepal } \\
\text { Bandh. }\end{array}$ \\
\hline 2 & SIP/ MC/ICB/01 & 36 & 44 & 1.2 & 8 & $t>1$ & 1670.49 & 1936.02 & 15.89 & $\mathrm{C}>1$ & $\begin{array}{l}\text { Delay due to decision of compensation } \\
\text { of land, land acquisition, scope of work } \\
\text { change, Variation of work, political } \\
\text { instability, Nepal Bandh. }\end{array}$ \\
\hline 3 & SIP/MC/NCB/01 & 24 & 36 & 1.5 & 12 & $t>1$ & 65 & 56.3 & 13.38 & $\mathrm{C}<1$ & $\begin{array}{l}\text { Delay due to decision of land } \\
\text { acquisition, scope of work change, } \\
\text { change in alignment, forest land } \\
\text { acquisition, political instability, Nepal } \\
\text { Bandh. }\end{array}$ \\
\hline 4 & SIP/MC/NCB/02 & 24 & 36 & 1.5 & 12 & $t>1$ & 52.07 & 42.74 & 17.91 & $\mathrm{C}<1$ & $\begin{array}{l}\text { Delay due to decision of land } \\
\text { acquisition, scope of work change, } \\
\text { change in alignment, forest land } \\
\text { acquisition, political instability, Nepal } \\
\text { Bandh. }\end{array}$ \\
\hline 5 & SIP/MC/NCB/03 & 24 & 36 & 1.5 & 12 & $t>1$ & 56.4 & 46.8 & $\begin{array}{l}- \\
17.02\end{array}$ & $\mathrm{C}<1$ & $\begin{array}{l}\text { Delay due to decision of land } \\
\text { acquisition, scope of work change, } \\
\text { change in alignment, forest land } \\
\text { acquisition, political instability, Nepal } \\
\text { Bandh. }\end{array}$ \\
\hline 6 & SIP/MC/ICB-02 & 38 & 41 & 1.1 & 3 & $t>1$ & 2117.56 & 3024.8 & 42.84 & $C>1$ & $\begin{array}{l}\text { Delay due to decision of land } \\
\text { acquisition, scope of work change, } \\
\text { change in alignment, Rastriya Nikunja } \\
\text { area land acquisition problem, political } \\
\text { instability, local people strick, heavy } \\
\text { cutting and heavy filling area, dispersive } \\
\text { soil zone area, action of CIAA, most of } \\
\text { area in Rastriya Nikunja and Forest. }\end{array}$ \\
\hline 7 & SIP/MC/ICB-03 & 30 & 34 & 1.1 & 4 & $t>1$ & 1635.82 & 1646.85 & 0.67 & $C>1$ & $\begin{array}{l}\text { Delay due to decision of land } \\
\text { acquisition, scope of work change, } \\
\text { Variation of work, political instability, } \\
\text { Nepal Bandh. }\end{array}$ \\
\hline 8 & $\begin{array}{l}\text { SIP/FDR/NCB- } \\
01\end{array}$ & 4 & 13 & 3.3 & 9 & $t>1$ & 85.18 & 89.63 & 5.22 & $\mathrm{C}>1$ & $\begin{array}{l}\text { Delay due to pre monsoon, } \\
\text { unavailability of construction material. }\end{array}$ \\
\hline 9 & $\begin{array}{l}\text { SIP/MC-RP/NCB- } \\
01\end{array}$ & 24 & 28 & 1.2 & 4 & $t>1$ & 17.8 & 16.74 & -5.95 & $\mathrm{C}<1$ & $\begin{array}{l}\text { Delay due to decision of land acquisition, } \\
\text { scope of work change, Variation of work, } \\
\text { political instability, Nepal Bandh. }\end{array}$ \\
\hline
\end{tabular}


International Journal of Case Studies in Business, IT, and Education (IJCSBE), ISSN: 2581-6942, Vol. 5, No. 1, June 2021

\begin{tabular}{|c|c|c|c|c|c|c|c|c|c|c|c|}
\hline 10 & $\begin{array}{l}\text { SIP/MC/Gate/NC } \\
\text { B-01 }\end{array}$ & 20 & 24 & 1.2 & 4 & $t>1$ & 23.3 & 22.12 & -5.06 & $\mathrm{C}<1$ & $\begin{array}{l}\text { Delay due to excess rain, flood in river, } \\
\text { scope of work change, Scarcity of } \\
\text { material, political instability. }\end{array}$ \\
\hline 11 & SIP/SBC/NCB-01 & 24 & 48 & 2 & 24 & $\mathrm{t}>1$ & 93.2 & 90.22 & -3.19 & $\mathrm{C}<1$ & $\begin{array}{l}\text { Delay due to pre monsoon, unavailability } \\
\text { of construction material. }\end{array}$ \\
\hline 12 & SIP/SBC/NCB-03 & 24 & 60 & 2.5 & 36 & $t>1$ & 124.23 & $\begin{array}{l}121.3 \\
6\end{array}$ & -2.31 & $\mathrm{C}<1$ & $\begin{array}{l}\text { Delay due to pre monsoon, unavailability } \\
\text { of construction material. }\end{array}$ \\
\hline 13 & SIP/CAP/NCB-06 & 8 & 11 & 1.4 & 3 & $t>1$ & 19.77 & 19.7 & -0.35 & $\mathrm{C}<1$ & $\begin{array}{l}\text { Delay due to pre monsoon, unavailability } \\
\text { of construction material (stone). }\end{array}$ \\
\hline 14 & SIP/CAP/NCB-07 & 11 & 33 & 3 & 22 & $\mathrm{t}>1$ & 105.98 & $\begin{array}{l}102.3 \\
8\end{array}$ & -3.39 & $\mathrm{C}<1$ & $\begin{array}{l}\text { Delay due to pre monsoon, unavailability } \\
\text { of construction material (stone). }\end{array}$ \\
\hline 15 & SIP/CAP/NCB-08 & 9 & 30 & 3.3 & 21 & $\mathrm{t}>1$ & 47.25 & 46.88 & -0.78 & $\mathrm{C}<1$ & $\begin{array}{l}\text { Delay due to pre monsoon, unavailability } \\
\text { of construction material (stone). }\end{array}$ \\
\hline 16 & SIP/CAP/NCB-13 & 10 & 22 & 2.2 & 12 & $t>1$ & 8.99 & 8.11 & -9.78 & $\mathrm{C}<1$ & $\begin{array}{l}\text { Delay due to pre monsoon, unavailability } \\
\text { of construction material (stone). }\end{array}$ \\
\hline & Average Total & $\begin{array}{l}22 . \\
1\end{array}$ & 34.4 & 1.8 & $\begin{array}{l}12 . \\
3\end{array}$ & & & & & & \\
\hline
\end{tabular}

Table 3: Ongoing project beyond schedule detail and cause

\begin{tabular}{|c|c|c|c|c|c|c|c|c|c|}
\hline$\dot{z}$ & 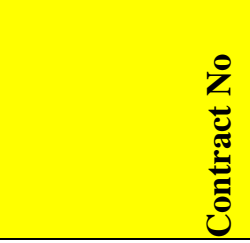 & 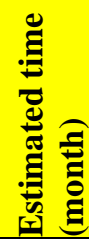 & 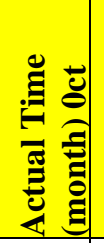 & 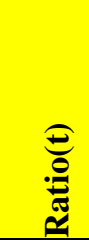 & 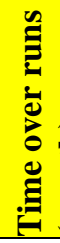 & 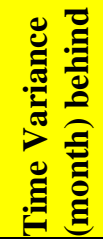 & 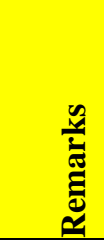 & 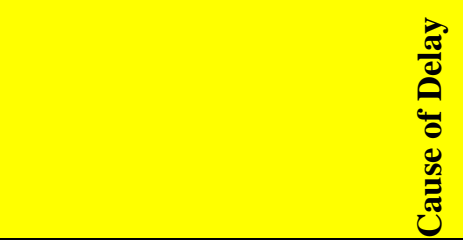 & 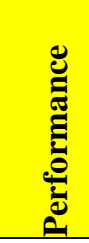 \\
\hline 1 & $\begin{array}{l}\text { SIP/EMC/ICB- } \\
01\end{array}$ & 28 & 42 & 1.5 & 14 & 15.1 & $t>1$ & $\begin{array}{l}\text { Delay in approval of site } \\
\text { clearance of tree in canal } \\
\text { alignment area, do not study } \\
\text { IEE of quarry site, so scarcity of } \\
\text { construction material, disputes } \\
\text { of fixing of canal alignment, pre } \\
\text { monsoon/ unpredictable } \\
\text { rainfall, bandh hartal covid-19 } \\
\text { lockdown. }\end{array}$ & $30 \%$ \\
\hline 2 & $\begin{array}{l}\text { SIP/SBC/NCB- } \\
02\end{array}$ & 25 & 78 & 3.12 & 53 & 9.75 & $t>1$ & $\begin{array}{l}\text { Delay decision of site clearance } \\
\text { of tree in canal alignment area, } \\
\text { unavailability of construction } \\
\text { material, disputes of fixing of } \\
\text { canal alignment, pre monsoon/ } \\
\text { unpredictable rainfall, bandh } \\
\text { hartal covid-19 lockdown. }\end{array}$ & $65 \%$ \\
\hline 3 & $\begin{array}{l}\text { SIP/CAP/NCB- } \\
04\end{array}$ & 13 & 39 & 3 & 26 & 17.9 & $t>1$ & $\begin{array}{l}\text { Delay due to decision of } \\
\text { embankment alignment in } \\
\text { Rastriya nikunj area pre } \\
\text { monsoon and high flood in } \\
\text { Jhijari khola, unavailability of } \\
\text { construction material, Covid } 19 \text {, } \\
\text { lockdown, delay decision of } \\
\text { changing alignment. }\end{array}$ & $96 \%$ \\
\hline 4 & $\begin{array}{l}\text { SIP/CAP/NCB- } \\
12\end{array}$ & 10 & 30 & 3 & 20 & 17.5 & $t>1$ & $\begin{array}{l}\text { Delay due to unavailability of } \\
\text { construction material, for rainy } \\
\text { season affect the transportation } \\
\text { of material due to blockage of } \\
\text { road. Stop quarry of material } \\
\text { from river, flood in Dudwa }\end{array}$ & $44 \%$ \\
\hline
\end{tabular}




\begin{tabular}{|c|c|c|c|c|c|c|c|c|c|}
\hline & & & & & & & & $\begin{array}{l}\text { khola due to heavy rainfall, } \\
\text { Covid-19 lockdown. }\end{array}$ & \\
\hline 5 & $\begin{array}{l}\text { SIP/CAP/NCB- } \\
15(\mathrm{Re})\end{array}$ & 12 & 30 & 2.5 & 18 & 14.2 & $t>1$ & $\begin{array}{l}\text { Delay due to unavailability of } \\
\text { construction material, } \\
\text { premonsoon flood in Jhijari } \\
\text { Khola, Stop quarry of material } \\
\text { from river, Covid-19 lockdown. }\end{array}$ & $50 \%$ \\
\hline 6 & $\begin{array}{l}\text { SIP/CAP/NCB- } \\
16\end{array}$ & 12 & 27 & 2.25 & 15 & 18.66 & $t>1$ & $\begin{array}{l}\text { Delay due to unavailability of } \\
\text { construction material, } \\
\text { premonsoon high flood in Rapti } \\
\text { River, Stop quarry of material } \\
\text { from river, Covid-19 lockdown. }\end{array}$ & $29 \%$ \\
\hline
\end{tabular}

\begin{tabular}{|c|c|c|c|c|c|c|c|c|c|}
\hline 7 & $\begin{array}{l}\text { SIP//DR/NCB- } \\
01\end{array}$ & 12 & 27 & 2.25 & 15 & 5.2 & $t>1$ & $\begin{array}{l}\text { Delay due to Land acquisition } \\
\text { of Kiran Nala Bank, pre } \\
\text { monsoon and high flood in } \\
\text { kiran nala, scarcity construction } \\
\text { material, Covid-19, lockdown }\end{array}$ & $74 \%$ \\
\hline 8 & $\begin{array}{l}\text { SIP//DR/NCB- } \\
02\end{array}$ & 12 & 29 & 2.41 & 17 & 11.8 & $\mathrm{t}>1$ & $\begin{array}{l}\text { Delay due to pre monsoon and } \\
\text { high flood in Pidari nala, } \\
\text { scarcity of construction } \\
\text { material, Covid19, lockdown }\end{array}$ & $44 \%$ \\
\hline 9 & $\begin{array}{l}\text { SIP/RMC/AKL/ } \\
\text { NCB-01 }\end{array}$ & 24 & 30 & 1.25 & 6 & $\begin{array}{l}13.9 \\
9\end{array}$ & $t>1$ & $\begin{array}{l}\text { delay decision to Land } \\
\text { acquisition of canal alignment, } \\
\text { delay decision of Kalo purja } \\
\text { land, delay decision of tree } \\
\text { clearance of canal alignment, } \\
\text { pre monsoon, unavailability of } \\
\text { construction material, Covid- } \\
19 \text {, lockdown }\end{array}$ & $42 \%$ \\
\hline 10 & $\begin{array}{l}\text { SIP/RMC/GHW } \\
\text { /NCB-01 }\end{array}$ & 24 & 30 & 1.25 & 6 & $\begin{array}{l}11.2 \\
5\end{array}$ & $t>1$ & $\begin{array}{l}\text { Delay decision to Land } \\
\text { acquisition of canal alignment, } \\
\text { delay decision of Kalo purja } \\
\text { land, delay decision of tree } \\
\text { clearance of canal alignment, } \\
\text { pre monsoon, unavailability of } \\
\text { construction material, Covid- } \\
\text { 19, lockdown }\end{array}$ & $49 \%$ \\
\hline 11 & $\begin{array}{l}\text { SIP/RMC/PRS/ } \\
\text { NCB-01 }\end{array}$ & 24 & 30 & 1.25 & 6 & $\begin{array}{l}15.9 \\
9\end{array}$ & $t>1$ & $\begin{array}{l}\text { Delay decision to Land } \\
\text { acquisition of canal alignment, } \\
\text { delay decision of Kalo purja } \\
\text { land, delay decision of tree } \\
\text { clearance of canal alignment, } \\
\text { premonsoon, unavailability of } \\
\text { construction material, Covid- } \\
19 \text {, lockdown }\end{array}$ & $29 \%$ \\
\hline 12 & $\begin{array}{l}\text { SIP/RMC/PDR/ } \\
\text { NCB-01 }\end{array}$ & 24 & 30 & 1.25 & 6 & $\begin{array}{l}21.8 \\
0\end{array}$ & $t>1$ & $\begin{array}{l}\text { Delay decision to Land } \\
\text { acquisition of canal alignment, } \\
\text { delay decision of Kalo purja } \\
\text { land, delay decision of tree } \\
\text { clearance of canal alignment, } \\
\text { pre monsoon, unavailability of } \\
\text { construction material, Covid- } \\
\text { 19, lockdown }\end{array}$ & $13 \%$ \\
\hline 13 & $\begin{array}{l}\text { SIP/SBC/NCB- } \\
04\end{array}$ & 12 & 18 & 1.5 & 6 & $\begin{array}{l}12.1 \\
0\end{array}$ & $t>1$ & $\begin{array}{l}\text { Delay due to Covid-19 luck } \\
\text { down, premonsoon, heavy } \\
\text { rainfall, unavailability of } \\
\text { construction material. }\end{array}$ & $18 \%$ \\
\hline
\end{tabular}


International Journal of Case Studies in Business, IT, and Education (IJCSBE), ISSN: 2581-6942, Vol. 5, No. 1, June 2021

\begin{tabular}{|c|c|c|c|c|c|c|c|c|c|}
\hline 14 & $\begin{array}{l}\text { SIP/DIS/NCB- } \\
01 / 076-077\end{array}$ & 12 & 12 & 1 & 0 & 3.3 & $\mathrm{t}=1$ & $\begin{array}{l}\text { Delay due to Covid-19 luck } \\
\text { down, premonsoon, heavy } \\
\text { rainfall and high flood in } \\
\text { Dudwa Khola. }\end{array}$ & $27 \%$ \\
\hline & $\begin{array}{l}\text { Total } \\
\text { (Average) }\end{array}$ & $\begin{array}{r}17.4 \\
2 \\
\end{array}$ & $\begin{array}{r}32.2 \\
8 \\
\end{array}$ & 1.96 & $\begin{array}{r}14.8 \\
5 \\
\end{array}$ & $\begin{array}{c}13.4 \\
6\end{array}$ & & & \\
\hline
\end{tabular}

Table 4: Soil Investigation Report

\begin{tabular}{|c|l|c|c|c|}
\hline S.N. & \multicolumn{1}{|c|}{ Sampling Location } & $\begin{array}{c}\text { Sampling } \\
\text { depth }(\mathbf{m})\end{array}$ & $\begin{array}{c}\text { Soil Dispersion in } \\
\mathbf{\%}\end{array}$ & Remarks \\
\hline 1 & Ch. 17+750 & 1.5 & 55.88 & Dispersive \\
\hline 2 & Balapur Cutting (Ch. 21+175) & 1.0 & 42.50 & Intermediate \\
\hline 3 & Ch. 21+750 & 1.0 & 48.78 & Intermediate \\
\hline 4 & Ch. 22+757 & 1.0 & 56.44 & Dispersive \\
\hline 5 & Ch. 23+996 & 1.0 & 45.55 & Intermediate \\
\hline 6 & Dhakeri (Ch. 24+054) & 1.0 & 29.9 & Intermediate \\
\hline 7 & Jhijhari downstream & 1.5 & 58.46 & Dispersive \\
\hline 8 & Jhijhari Filling (UD) & 1.0 & 11.32 & Non Dispersive \\
\hline 9 & Jhijhari Cutting & 1.5 & 58.75 & Dispersive \\
\hline 10 & Chainage 27+750 & 1.0 & 48.56 & Intermediate \\
\hline 11 & Sidhhania & 1.0 & 33.33 & Intermediate \\
\hline 12 & Chadi Bhagra & 1.5 & 43.26 & Intermediate \\
\hline 13 & Most disturbed Part & 1.5 & 60.64 & Dispersive \\
\hline 14 & Dunduwa Filling & 1.5 & 46.67 & Intermediate \\
\hline 15 & Purwa & 35.41 & Intermediate \\
\hline
\end{tabular}

(Source: refer table 1 from methodology)

In SIP the most of contract awarded after only the land acquired so it delays projects. SIP was land acquisition and compensation for the land up to f.y. 2076/077 has total 87.19 ha.

\subsection{Extension of Time:}

Table 5 : Detail of Time of Extension of contract

\begin{tabular}{|c|c|c|c|c|c|c|c|c|}
\hline$\underset{\dot{S}}{\dot{L}}$ & 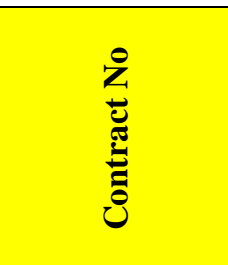 & 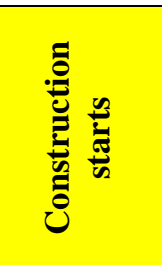 & 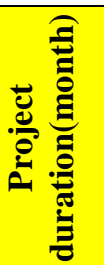 & 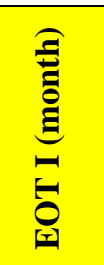 & 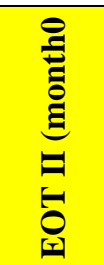 & 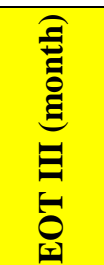 & 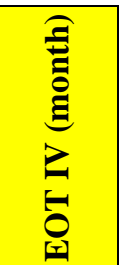 & 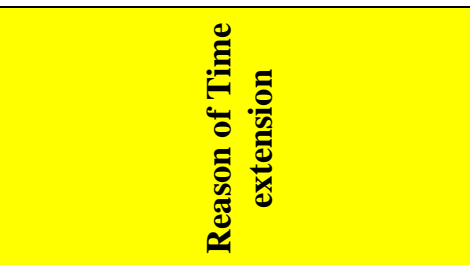 \\
\hline 1 & $\begin{array}{l}\text { SIP/EMC/ICB } \\
-01\end{array}$ & 24-Jul-17 & 28 & 14 & - & - & - & $\begin{array}{l}\text { Delay in approval of site } \\
\text { clearance of tree in canal } \\
\text { alignment area, do not study } \\
\text { IEE of quarry site, so scarcity of } \\
\text { construction material, disputes } \\
\text { of fixing of canal alignment, pre } \\
\text { monsoon/ unpredictable rainfall, } \\
\text { bandh hartal covid-19 } \\
\text { lockdown. }\end{array}$ \\
\hline 2 & $\begin{array}{l}\text { SIP/SBC/NC } \\
\text { B-02 }\end{array}$ & 12-Jun-14 & 25 & 12 & 24 & 12 & 5 & $\begin{array}{l}\text { Delay decision of site clearance } \\
\text { of tree in canal alignment area, } \\
\text { unavailability of construction } \\
\text { material, disputes of fixing of } \\
\text { canal alignment, pre monsoon/ } \\
\text { unpredictable rainfall, bandh } \\
\text { hartal covid-19 lockdown. }\end{array}$ \\
\hline 3 & $\begin{array}{l}\text { SIP/CAP/NCB } \\
-02\end{array}$ & - & 27 & - & - & - & - & $\begin{array}{l}\text { Delay due to premonsoon, } \\
\text { unavailability of construction } \\
\text { material, contractor delay work, }\end{array}$ \\
\hline
\end{tabular}




\begin{tabular}{|c|c|c|c|c|c|c|c|c|}
\hline & & & & & & & & $\begin{array}{l}\text { Covid-19, lockdown, bandh } \\
\text { hartal. }\end{array}$ \\
\hline 4 & $\begin{array}{l}\text { SIP/CAP/NCB } \\
-04\end{array}$ & 21-Jun-17 & 13 & 6 & - & 20 & & $\begin{array}{l}\text { Delay due to decision of } \\
\text { embankment alignment in } \\
\text { Rastriya nikunj area pre } \\
\text { monsoon and high flood in } \\
\text { Jhijari khola, unavailability of } \\
\text { construction material, Covid19, } \\
\text { lockdown, delay decision of } \\
\text { changing alignment. }\end{array}$ \\
\hline 5 & $\begin{array}{l}\text { SIP/CAP/NCB } \\
-12\end{array}$ & 04-Jun-18 & 10 & 6 & 8 & 6 & & $\begin{array}{l}\text { Delay due to unavailability of } \\
\text { construction material, for rainy } \\
\text { season affect the transportation } \\
\text { of material due to blockage of } \\
\text { road. Stop quarry of material } \\
\text { from river flood in Dudwa } \\
\text { kkhola due to heavy rainfall, } \\
\text { Covid-19 lockdown. }\end{array}$ \\
\hline 6 & $\begin{array}{l}\text { SIP/CAP/NCB } \\
-15(\operatorname{Re})\end{array}$ & 06-Jul-18 & 12 & 3 & 3 & 6 & 6 & $\begin{array}{l}\text { Delay due to unavailability of } \\
\text { construction material, } \\
\text { premonsoon flood in Jhijari } \\
\text { Khola, Stop quarry of material } \\
\text { from river, Covid-19 lockdown. }\end{array}$ \\
\hline 7 & $\begin{array}{l}\text { SIP/CAP/NCB } \\
-16\end{array}$ & 05-Jul-18 & 12 & 3 & 3 & 9 & - & $\begin{array}{l}\text { Delay due to unavailability of } \\
\text { construction material, } \\
\text { premonsoon high flood in Rapti } \\
\text { River, Stop quarry of material } \\
\text { from river, Covid-19 lockdown. }\end{array}$ \\
\hline 8 & $\begin{array}{l}\text { SIP//DR/NCB- } \\
01\end{array}$ & 02-Jul-18 & 12 & 6 & 9 & - & - & $\begin{array}{l}\text { delay due to Land acquisition of } \\
\text { Kiran Nala Bank, pre monsoon } \\
\text { and high flood in kiran nala, } \\
\text { scarcity construction material, } \\
\text { Covid-19, lockdown }\end{array}$ \\
\hline 9 & $\begin{array}{l}\text { SIP//DR/NCB- } \\
02\end{array}$ & 02-Jul-18 & 12 & 3 & 8 & 6 & - & $\begin{array}{l}\text { delay due to pre monsoon and } \\
\text { high flood in Pidari nala, } \\
\text { scarcity of construction } \\
\text { material, Covid19, lockdown }\end{array}$ \\
\hline 10 & $\begin{array}{l}\text { SIP/RMC/AK } \\
\text { L/NCB-01 }\end{array}$ & 03-Jul-18 & 24 & 6 & - & - & - & $\begin{array}{l}\text { delay decision to Land } \\
\text { acquisition of canal alignment, } \\
\text { delay decision of Kalo purja } \\
\text { land, delay decision of tree } \\
\text { clearance of canal alignment, } \\
\text { premonsoon. unavailability of } \\
\text { construction material, Covid-19, } \\
\text { lockdown }\end{array}$ \\
\hline 11 & $\begin{array}{l}\text { SIP/RMC/GH } \\
\text { W/NCB-01 }\end{array}$ & 03-Jul-18 & 24 & 6 & - & - & - & $\begin{array}{l}\text { delay decision to Land } \\
\text { acquisition of canal alignment, } \\
\text { delay decision of Kalo purja } \\
\text { land, delay decision of tree } \\
\text { clearance of canal alignment, } \\
\text { pre monsoon, unavailability of } \\
\text { construction material, Covid-19, } \\
\text { lockdown }\end{array}$ \\
\hline 12 & $\begin{array}{l}\text { SIP/RMC/PR } \\
\text { S/NCB-01 }\end{array}$ & 03-Jul-18 & 24 & 6 & - & - & - & \begin{tabular}{|l} 
delay decision to Land \\
acquisition of canal alignment, \\
delay decision of Kalo purja \\
land, delay decision of tree \\
clearance of canal alignment, \\
pre monsoon, unavailability of
\end{tabular} \\
\hline
\end{tabular}




\begin{tabular}{|l|l|l|l|l|l|l|l|l|} 
& & & & & & & $\begin{array}{l}\text { construction material, Covid-19, } \\
\text { lockdown }\end{array}$ \\
\hline $\mathbf{1 3}$ & $\begin{array}{l}\text { SIP/RMC/PD } \\
\text { R/NCB-01 }\end{array}$ & 03-Jul-18 & 24 & 6 & - & - & - & $\begin{array}{l}\text { delay decision to Land } \\
\text { acquisition of canal alignment, } \\
\text { delay decision of Kalo purja } \\
\text { land, delay decision of tree } \\
\text { clearance of canal alignment, } \\
\text { pre monsoon, unavailability of } \\
\text { construction material, Covid-19, } \\
\text { lockdown }\end{array}$ \\
\hline $\mathbf{1 4}$ & $\begin{array}{l}\text { SIP/SBC/NC } \\
\text { B-04 }\end{array}$ & $\begin{array}{c}\text { 19-May- } \\
19\end{array}$ & 12 & 6 & - & - & - & $\begin{array}{l}\text { Delay due to Covid-19 luck } \\
\text { down, premonsoon, heavy } \\
\text { rainfall, unavailability of } \\
\text { construction material. }\end{array}$ \\
\hline
\end{tabular}

Major factors affecting the project performance identified were

1. Natural Catastrophes, Rainfall and Premonsoon

2. Land Issue, Blockade

3. Scarcity of the materials and

4. Design change

5. Covid-19 Luck down

Item numbers (1), (2) and (3) above are considered as force majeure according to the respective contract documents. Item number (4) is also the delay causing events whose ownership lies solely upon the Client. number (5) is also the delay causing events due to covid -19 corona virus epidermic and lockdown. Hence for all above issues, the contractor is liable for time extensions. It is to be noted here that all projects under study have followed the General Conditions of Contract of the Standard bid Document of the public Procurement Monitoring office for Time Schedules and Extensions. The EOT1, EOT2, EoT3 for all projects were granted in accordance with the Section 56 of public procurement act and section 120 of public procurement rule. The General Conditions of Contract of SBD by PPMO has clearly stated that the contractors, after commencement of work, must submit the detailed work schedule and the program needs to be updated as stipulated in the documents. On Contrary, the program submitted by the contractor, though the critical path method has been used, is not satisfactory. The major stages of work and the detailed work breakdown structures are missing in initially submitted baseline programs. None of the contractors has submitted the updated program to claim for extension of time. For EOT 4 of all projects under study, no substantial and responsive reasons have been found sofar.

\subsection{Disputes of Contract:}

The sikta irrigation project contract no SIP/DIS/MC/ICB-01 the contractor Papu costal J.V, Tinkune, Kathmandu. Fails to construct of irrigation canal in timely so the employer i.e., SIP has terminated the contract (Table 6).

Table 6: Detail of Termination of Contract

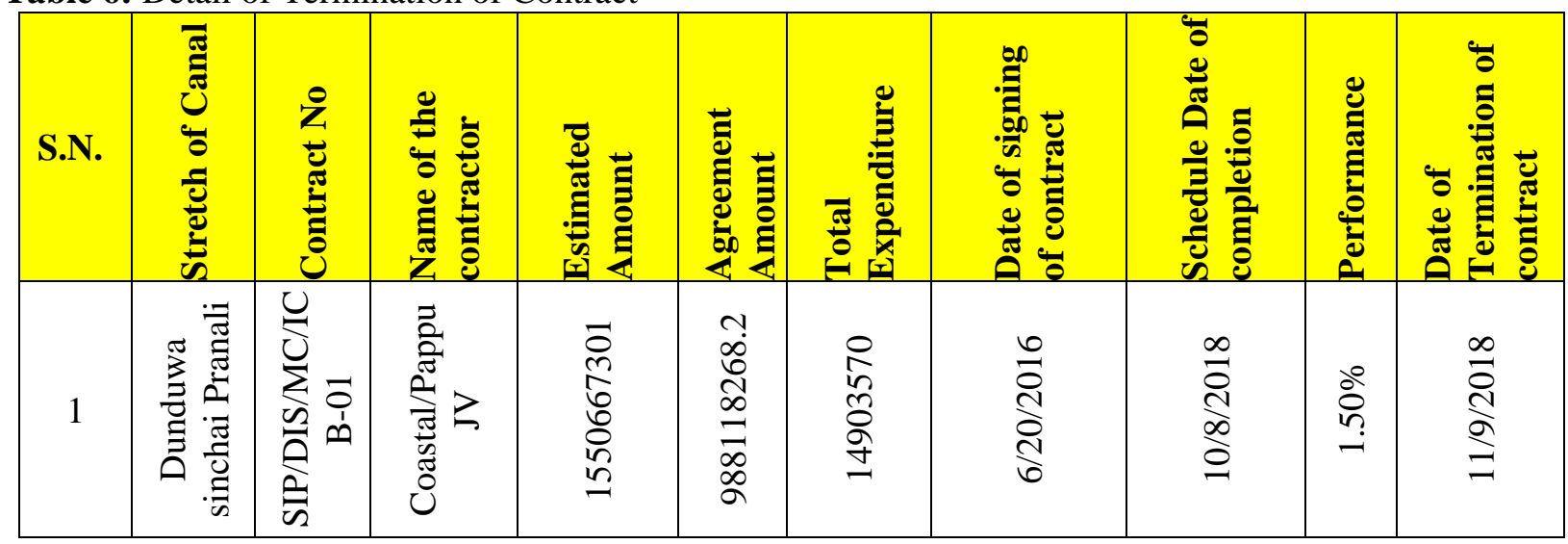

The Construction of main canal, link canals and Rehabilitation of Head Work of Dunduwa Irrigation 
System was signed on 20th June 2016 between Agreement of Irrigation Ministry of Government of Nepal as the employer one party and other parts namely Ms. Coastal Papu Jv, Tinkune, Kathmandu as the contractor the other party. The Commencement date as per the condition of the contract was 30 days after contract signing date and the contract completion date was October 8, 2018 i.e., 840 days (28 month). The contractor did not perform the anticipated work progress as per original construction schedule.

Consultant working on behalf of employer had a first triparties meeting with contractor on November 2016 and contractor discrepancies in compliance with the contract were noted in the minutes of meeting. Again, second triparties meeting was held on January 26, 2017 on which contactor discrepancies were noted and contractor were asked to comply in accordance with the contract. As contractor progress was very much slow and were required to fulfill a number of contractual obligation and also noted the progress of the work up of that period was only $1.5 \%$ and advised contractor to improve planning and management to expedite the work. Contractor had given a letter of commitment of May 11, 2017 stating that you could complete about $15 \%$ of the work within the running fiscal year and the remaining work in the following fiscal year as per contract. SIP letter dated June 29, 2017 about the progress of construction works had warned contractor among other thing contractor were not working properly and making a number of baseless claims (SIP letter, 2018) [2].

However, through SIP letter date September 14, 2017 had warned contractor that in the event of contract not completing within the stipulated time delay damages as per clause 8.7 and further clause 15.2 of the conditions of contract could also be involved. Similarly, have noted in the letter of October 2017 that delay in construction was due to contraction was due to contractor fault. Two public notices were issued to contractor in English daily newspaper, one published on October 26 and the other was published on December 12, 2017 contractor response to the first notice was found to be unsatisfactory and for the second notice contractor partner in charge of the JV failed to turned up within 15 days as notified. This information together with the opinion of Department of Irrigation had been given to contractor through SIP letter dated January 23,2018. In the third tripartite meeting held on February 11, 2018 a number of decisions were made among the other joints the point no (6) noted. "The Employer and the consultant assured the Contractor for necessary technical support and requested the contractor to grab and utilize this last opportunity, as in case the Employer is not convinced fully of the Contractor's sincere dedication and progress regarding the execution of the works by the end of February 2018, the Employer will initiate the process to terminate the contract. The contractor assured to fully utilized the planned progress, and agreed that the contractor to the role bearer for any legal action taken by the Employer in case of default". In outcome of the above meeting and on the recommendation of the Consultant SIP had given approval of the revised work schedule on February 20, 2018 submitted by contractor on February 16, 2018. SIP letter to you on April 11, 2018 titled " Why should not SIP initiate Contract Termination?" among other things concluded "Hence, contractor are hereby notified to come up in person together with the lead partner and authorized representative with an immediate clarification and any plausible argument on how M/S Costal-pappu JV Has not renegade on the renewed commitment to execute and complete the works, and why the employer should not take recourse to terminating the contract in accordance with GCC Clause 15.2(b) within 15(fifteen) days of receiving this letter".

Despite our good gesture and providing contractor ample opportunities to contractor for the execution of work you did not put committed efforts and contractor were being sheer negligent and will fully and deliberately not working at site and even in management meeting on 12 October 2018 no responsible person (either lead partner or the authorized representative) attended the same. The latest progress of your work at the expiry of contract period is only $7 \%$ as noted by the Consultation in the latest monthly progress report of August 2018.

The Saudi Fund for Development letter (Ref. No. OD-2018/23651, Dated 06-05-2018) to SIP are kindly requested to take all necessary action to avoid any financial burden such as forfeiting the performance and advance payment guarantees the proceed with contract, termination and SFD concluded in view of all above mentioned facts and findings that since it is impossible to achieve considerable progress by the end of March 2018 contract must be terminated. Therefore, SFD will stop processing any payment to this contract. The consultant CMS-FBC joint ventures over all physical progress report 07 October 2018 of contract has approximately $6.7 \%$ so, advise that contractor has time and against failed to improve the management and achieve the necessary progress hence extending time seems to be wastage of time and termination of the contract will be better opinion. It has no other alternative than to terminate 
contract as contractor have plainly demonstrated that contractor intention not to continue performance of obligation under the contract. The Contract agreement General/condition of contract clause 15.2 Termination by employer. The Employer shall be entitled to terminate the contract if the contractor (b) obligations under the contract. Therefore, SIP hereby give 14 days' notice as per clause 15 sub-clause 15.2(b) of the condition of contract for the termination of the contract to the contractor: M/s CoastalPappu Jv, Tinkune Kathmandu.

Table 7: Cause - Effect Analysis

\begin{tabular}{|c|c|c|c|}
\hline & Contractor & Owner (GoN, SIP) & Analysis \\
\hline Cause & $\begin{array}{l}\text { The various delay event } \\
\text { which fall under } \\
\text { compensation } \\
\text { event/employer's } \\
\text { liability pursuant to } \\
\text { sub-clause } 8.4 \text { and } 20.1 \\
\text { of condition of contract } \\
\text { are no site possession, } \\
\text { delay in providing } \\
\text { reviewed design } \\
\text { drawing, delay in } \\
\text { approval of working } \\
\text { drawing, delay due to } \\
\text { re-doing of earlier } \\
\text { works due to change of } \\
\text { Project director and } \\
\text { SDE, delay due to } \\
\text { obstruction by locals ( } \\
\text { from ch.15+800 to ch } \\
23+235 \text { ), delay } \\
\text { permission of tree } \\
\text { cutting by government } \\
\text { entities, delay due to } \\
\text { relocation of utilities, } \\
\text { delay due to lack of } \\
\text { permission of river bed } \\
\text { material, delay due to } \\
\text { holidays and election } \\
\text { and delay due to } \\
\text { closure of quarry site } \\
\text { by GoN. Due to } \\
\text { occurrence of various } \\
\text { delay events beyond } \\
\text { the control of } \\
\text { contractor the work has } \\
\text { not been completed } \\
\text { within the scheduled } \\
\text { time. Based on above } \\
\text { delay the contractor } \\
\text { entitled for extension of } \\
\text { time by } 540 \text { days. }\end{array}$ & $\begin{array}{l}\text { The Contractor did not } \\
\text { perform the anticipated work } \\
\text { progress as per work schedule } \\
\text { (28-month contract period). } \\
\text { As contractor progress }(6.7 \%) \\
\text { as was very much slow and } \\
\text { were required to fulfill a } \\
\text { number of contractual } \\
\text { obligations. First triparties } \\
\text { meeting (Nov 2016) and } \\
\text { second triparties meeting } \\
\text { (26th Jan. 2017) was held on } \\
\text { which contractor } \\
\text { discrepancies were noted. } \\
\text { Engineer team visited the site } \\
\text { not found the any } \\
\text { representative of the } \\
\text { contractor. }\end{array}$ & $\begin{array}{l}\text { From Annex (table A.17) } \\
\text { it was found that } \\
\text { availability of site, } \\
\text { approval of clearance of } \\
\text { tree and approval river } \\
\text { bed material quarry site } \\
\text { all are available in timely } \\
\text { by SIP. The submitted } \\
\text { construction drawing by } \\
\text { contractor are some parts } \\
\text { mistakes so the SIP delay } \\
\text { approved construction } \\
\text { drawing } 1.5 \text { Km only. but } \\
\text { the contractor fails to } \\
\text { submitted the remaining } \\
\text { correct construction } \\
\text { drawing and } \\
\text { construction work of } 1.5 \\
\text { km during whole contract } \\
\text { period (28 month). The } \\
\text { slow progress (6.7\%) of } \\
\text { work by contractor }\end{array}$ \\
\hline
\end{tabular}




\begin{tabular}{|c|c|c|c|}
\hline Responsibility & $\begin{array}{l}\text { Delay in providing } \\
\text { reviewed design } \\
\text { drawing, delay in } \\
\text { approval of } \\
\text { construction drawing, } \\
\text { delay in approval of } \\
\text { working drawing, delay } \\
\text { permission of tree } \\
\text { cutting by government } \\
\text { entities all the delay } \\
\text { responsible to the Sikta } \\
\text { Irrigation Project } \\
\text { office. }\end{array}$ & $\begin{array}{l}\text { Timely approved the } \\
\text { construction drawing up to } 1.5 \\
\mathrm{~km} \text { but not work perform. All } \\
\text { the delay are contractor delay. } \\
\text { It is responsible to all the } \\
\text { obligation. The Saudi fund for } \\
\text { development to SIP are kindly } \\
\text { requested to take all necessary } \\
\text { action to the contractor. } \\
\text { General condition of contract } \\
\text { clause } 15.20 \text { termination by } \\
\text { employer, the employer shall } \\
\text { be entitled to terminate the } \\
\text { contract if the contractor } \\
\text { abandons the works or not to } \\
\text { continue performance of his } \\
\text { obligations under the contract. } \\
\text { According to this clause DOI } \\
\text { has terminated the contract. }\end{array}$ & $\begin{array}{l}\text { Due to delay of contract } \\
\text { affect the } 16000 \text { ha land } \\
\text { of farmer so main } \\
\text { responsible of the project } \\
\text { are contractor fault. It was } \\
\text { Saudi funded project, } \\
\text { Saudi development fund } \\
\text { letter on dated } 2018 \text { says } \\
\text { that all necessary action to } \\
\text { avoid any financial } \\
\text { burden such as forfeiting } \\
\text { the performance and } \\
\text { advance payment } \\
\text { guarantees then proceed } \\
\text { with contract termination. } \\
\text { It was good decision to } \\
\text { take the action against } \\
\text { contractor by DWRI was } \\
\text { terminated the contract } \\
\text { under GCC clause } 15.2 \text {. }\end{array}$ \\
\hline
\end{tabular}

International Federation of Consulting Engineers (FIDIC) condition of contract for construction, for building and engineering works designed by the employer, Multilateral Development Bank Harmonized edition June 2010 of General Conditions Clause 15 termination by employer. General condition of contract clause 15.2 Termination by Employer. The employer shall be entitled to terminate the Contract if the contractor (b) abandons the works or otherwise plainly demonstrates the intention not to continue performance of his obligations under the contract. According to this clause the Department of Irrigation has terminated the contract (Table 7).

\section{CONCLUSION :}

Sikta Irrigation Project has total 52 contracts out of which 51 consider for study based on documentation, only 18 contracts completed based on schedule time whereas 16 contracts behind the schedule. However, 16 contracts are still on going far behind the schedule and one contract terminated. The mean planned duration of the projects under the study is 17.42 month and mean actual time 32.28 month with standard deviation of 7.72 month and mean time variance is 13.46 month behind the schedule and mean time overrun is 14.85 month are usually imparted due to poor project performance in construction of SIP. The entire ongoing project has behind the schedule time overrun. As contract no SIP/DIS/MC/ICB-01 the contractor Papu costal JV of progress was very much slow and was required to fulfill a number of contractual obligations and also noted the progress of the work up of that period was only $1.5 \%$ up to completion dated. The SIP has not extended the time of completion. The employer shall be entitled to terminate the Contract if the contractor (b) abandons the works or otherwise plainly demonstrates the intention not to continue performance of his obligations under the contract. According to this clause the Department of Irrigation has terminated the contract.

\section{RECOMMENDATIONS :}

Client should prepare the project well before implementation with proper planning, designing and detail study from the beginning. The client should be followed provision of PPA 2007 and PPR for extension of time in all contracts. SIP should use EVA and S-curve for all the contract for proper monitoring. Consultant should be pre-execution preparation of land acquisition, EIA, IEE and planning of project tasks, resource need and resource planning. Contractor should proper planning and management of qualified technical staff and construction material. Contractor should be advance purchase agreement the probable incidence in order to avoid shortage of construction material. Hope the amendment of extension of time clause will be significant for managing the time performance. 


\section{ACKNOWLEDGEMENT :}

Thank God for giving such a great ability to Er. Prakash Yadav for staying at site and working such a hard and some part of it used for his master's thesis also.

\section{REFERENCES :}

[1] Mishra, A. K., \& Aithal P. S., (2021). Foreign Aid Contribution for the Development of Nepal. International Journal of Management, Technology, and Social Sciences (IJMTS), 6(1), 162-169.

[2] Sikta Irrigation Project Master Plan 2007 and 2014 and 2019, Nepalgunj, Banke. www.doi.gov.np

[3] Chiluwal K., Mishra A. K. (2017). Construction Practice of Small Hydropower Projects in Nepal, International Journal of Creative Research Thoughts, 5(4), 1417-1433.

[4] Maskey A, Mishra A. K., (2018). Labor Productivity Assessment of Armed Police Force Nepal Building Construction Projects. International Journal of Current Research, 10(11), 75315-75324.

[5] Haseeb, M.et al., (2011). Causes and Effects of Delays in large construction projects of Pakistan. Kuwait chapter of Arabian journal of Business and Management Review, 1(4), 18-25.

[6] Mishra, A. K., \& Aithal, P. S. (2020). Financial Impact Assessment of Time Overrun: A Case of Second Small Towns Water Supply and Sanitation Sector Project. Nepal International Journal of Applied Engineering and Management Letters (IJAEML), 4(2), 159-173.

[7] Mishra, A. K., (2020). Project Management: Theory and Practice from Different Countries. PROJECT MANAGEMENT (p. 345). Tamilnadu: DK International Research Foundation. http://doi.org/10.5281/zenodo.4817542.

[8] Gil, N., Tommelein, I. D., Kirkendall, R. L., Ballard, G., (2001). Leveraging Specialty-Contraxtor knowledge in design-build organizations. Engineering construction and Architectural Management, 8(5-6), 355-367.

[9] Ghimire, S. \& Mishra, A. K. (2019). Comparative Study of Prospective Delay Analysis Techniques (DATs). Saudi J Civ Eng., 3(5), 84-95.

[10] Yadav, S. K., \& Mishra, A. K. (2019). Status of Time and Cost Overrun of Health Building Construction Projects in Nepal. Sch J Eng Tech, 7(9), 262-270.

[11] Mishra, A. K., Sudarsan, J.S. \& Nithiyanantham, S. (2021). Assessment of time-cost model of public health buildings in Nepal. Asian J Civ Eng, 22(1), 13-22. https://doi.org/10.1007/s42107020-00294-4.

[12] GoN, Public Procurement Act, GoN, Public Procurement Regulation based on Amendment, 2020. www.ppmo.gov.np

[13] Mishra A. K, Mandal L, Pant R. R. (2018). Causes of Dispute in International Competitive Bidding Road Contracts Funded by Asian Development Bank in Nepal. J Adv Res Busi Law Tech Mgmt, 1(3), 5-16.

[14] Mishra A. K. (2018). Dispute Resolution Practice of Project Management in Nepal. J Adv Res Busi Law Tech Mgmt, 1(4), 1-11. 